\title{
Integration of soil magnetometry and geochemistry for assessment of human health risk from metallurgical slag dumps
}

\author{
Marzena Rachwal $^{1}$ (D) $\cdot$ Malgorzata Wawer $^{1} \cdot$ Tadeusz Magiera $^{1} \cdot$ Eiliv Steinnes $^{2}$
}

Received: 29 May 2017 / Accepted: 13 September 2017 / Published online: 25 September 2017

(C) The Author(s) 2017. This article is an open access publication

\begin{abstract}
The main objective of the study was an assessment of the pollution level of agricultural land located close to dumps of industrial waste remaining after former $\mathrm{Zn}$ and $\mathrm{Pb}$ ore processing in Poland. The integrated geophysicalgeochemical methods were applied for assessment of soil quality with respect to trace element pollution. Additionally, human health risk induced by the contaminated arable soil and dusting slag heap was estimated. The investigations pointed out that soils in the vicinity of the metallurgical slag dump in Piekary were heavily polluted. Spatial distribution of magnetic susceptibility corresponding well with distribution of the content of potentially toxic elements indicated the local "pollution hotspots." Proper geophysical and geochemical data interpretation supported by statistical factor analysis enabled identification of three different sources of pollution including metallurgical slug dump as a main source, but also traffic pollution influencing the area located along the busy road and relatively strong influence of the geochemical background. Computed health hazard index revealed no adverse health effect to the farmers cultivating arable soil, but in the direct vicinity of dusting, slag dump health risk occurred, caused mostly by very toxic elements as As and Tl. In the future, investigation should be focused on contribution of different sources to the heavy metal pollution in soil-crop system
\end{abstract}

Responsible editor: Philippe Garrigues

Marzena Rachwał

marzena.rachwal@ipis.zabrze.pl

1 Institute of Environmental Engineering, Polish Academy of Sciences, 34 Sklodowska-Curie St, 41-819 Zabrze, Poland

2 Department of Chemistry, Norwegian University of Science and Technology, Høgskoleringen 5, N-7491 Trondheim, Norway in this area. It should be highlighted that a site-specific approach should be taken in order to redevelop this kind of area in order to reduce ecological and human health threat. The study proved the integrated two-stage geophysical-geochemical method to be a feasible, reliable, and cost-effective tool for identification of the extent of soil pollution and areas at risk.

Keywords Soil magnetometry · Potentially toxic elements · $\mathrm{Zn} / \mathrm{Pb}$-bearing ore smelting $\cdot$ Human health hazard index . Pollution load index $\cdot$ Index of geoaccumulation

\section{Introduction}

Upper Silesia is the most urbanized and industrialized region of Poland and correspondingly the most polluted region of Poland (Dziubanek et al. 2017). Rich deposits of hard coal as well as zinc, lead, iron, and silver ores led to development of mining and metallurgical industry since the twelfth century. Nowadays, it is nearly impossible to find an area in this region that is not transformed by human activity. Numerous shafts, excavations, mine waste heaps, and subsiding troughs are inseparable views in Upper Silesia. There are numerous metalrich waste heaps related to historical ore mining and processing being among the most significant sources of heavy metal contamination (Rożek et al. 2015; Warchulski et al. 2015). Such anthropogenic activities have generally influenced the conditions of water and soil (Merrington and Alloway 1997; Cabała et al. 2008). In addition, the presence of heavy metals may significantly influence the health of human beings as well as other organisms (Lanphear et al. 1998; Kozłowska et al. 2015). Hence, investigating and monitoring heavy metal pollution in soils is important. Soils in the vicinity and even at long distance from industrial sources are under influence of 
long-lasting emissions and deposition of potentially toxic elements (PTEs). These substances are present in urban and industrial dusts and can be deposited directly on soils or transported far away from the source (Steinnes et al. 1997; Steinnes and Friedland 2006).

Industrial emissions are also very important sources of technogenic magnetic particles (TMPs), mainly Fe oxides and hydroxides, which are generated in a wide variety of high-temperature technological processes, where different iron minerals, present in raw materials, fuels, and additives, are transformed into highly magnetic iron oxides (Magiera et al. 2011a). What is more, TMPs are known to be carriers of various pollutants such as heavy metals (Hunt et al. 1984; Beckwith et al. 1986; Strzyszcz 1993). Their presence in a material can be easily identified with magnetic susceptibility measurements, which are fast and relatively inexpensive. This proxy method based on the correlation between the topsoil magnetic susceptibility and the contents of PTE (mostly heavy metals) has been successfully used since the 1990s to detect and assess soil pollution with PTE (Strzyszcz et al. 1996; Petrovský et al. 2000; Wang and Qin 2006; Magiera et al. 2007; Jordanova et al. 2008; Cao et al. 2015). Therefore, magnetic susceptibility is an easy measurable general indicator of atmospherically derived particulate matter. The value of PTE itself reflects the general abundance of these elements, but to assess the overall level of contamination caused by particular or multiple elements, different methods and calculations, such as enrichment factor, contamination factor, geoaccumulation index (Igeo), pollution load index (PLI), and potential hazard index (HI), have been widely used (i.a. Jordanova et al. 2013; Li et al. 2014; Baran and Wieczorek 2015; Cao et al. 2015; Rachwał et al. 2015, 2017; Qing et al. 2015; Bourliva et al. 2017). Soil contamination by PTE, especially heavy metals and its possible consequences, was reported by many researchers from around the world where metal ore-bearing rocks have been exploited and smelted (McMartin et al. 2002; Svendsen et al. 2011; Šajn et al. 2013; Vaněk et al. 2013; Chrastný et al. 2015; Kapusta and Sobczyk 2015; Ettler 2016; Kríbek et al. 2016). Generally, the metallurgical wastes and ore processing itself were treated as the single pollution source.

The present study aimed at an assessment of the level of pollution of agricultural land located close to the dumps of industrial wastes remaining after $\mathrm{Zn}$ and $\mathrm{Pb}$ ore processing at Piekary Ślaskie, located in the northern part of the Upper Silesian Industrial Region (USIR). This site was chosen among several pilot sites differing in character and extent of pollution which were investigated within the frame of the IMPACT project (development of integrated geophysical/ geochemical methods of soil and groundwater pollution assessment and control in problematic areas) aimed at development of integrated two-stage geophysical/geochemical methods of evaluation of soil pollution and assessment of risk to sustainability of soil and groundwater. Moreover, an effort was made to assess the human health risk induced by the contaminated arable soil and dusting slag heap. This research applies magnetic susceptibility as the proxy tool, traditional geochemical analyses, computed pollution, and health hazard indices as well as correlation and PCA analyses. Therefore, it provides more complex, comparing with previous investigations, information about source-diversified soil contamination and its assessment in relation with human health.

\section{Studied area}

The town of Piekary Śląskie (in the following named Piekary) is located in Silesia, southern Poland, near the city of Katowice. It covers an area of $40 \mathrm{~km}^{2}$ and has population of 54,600. The town is located at the Silesia-Cracow monocline in the region where the richest resources of zinc and lead ores in Poland occur. Strata-bound $\mathrm{Zn}-\mathrm{Pb}$ deposits of the Mississippi Valley Type in this region consist mainly of sulfides occurring 40 to $240 \mathrm{~m}$ below surface. Those deposits are bounded to the Middle Triassic ore-bearing dolomites of Muschelkalk (Górecka 1993). Besides Pb and $\mathrm{Zn}$, the deposits contain $\mathrm{Cd}$; $\mathrm{Fe} ; \mathrm{Mn}$; and in smaller amounts Ag, Sb, Cu, As, Tl, Ge, Co, Mo, Ni, Bi, Ba, and Sr (Gałkiewicz and Śliwiński 1983).

The Piekary area has been monitored during recent years for several parameters, e.g., Warchulski et al. (2015) reported a potential environmental impact of harmful elements $(\mathrm{Pb}, \mathrm{Zn}$, and As) leaching from smelting slags, while Ullrich et al. (1999) as well as Kulka and Gzyl (2008) concluded that soils in the Bytom and Piekary area were significantly contaminated by $\mathrm{Zn}, \mathrm{Pb}, \mathrm{Cd}$, and $\mathrm{As}$ and should be withdrawn from agricultural production. Unfortunately, $60 \%$ of the study area consists of arable land where field workers cultivate consumable vegetables and where the main pollution source is not only the dusting slag heap but also industrial emissions, traffic-related pollution from the adjacent national road No. 94, and the contaminated soil itself. Therefore, the assessment of soil contamination level should be carried out parallel to simultaneous estimation of human health risk, which is caused mainly by metals and metalloids contained in investigated soils and wastes.

Studies were carried out within a $1-\mathrm{km}^{2}$ area of arable land. The field was located in the prevailing wind direction about $800 \mathrm{~m}$ east from a large dump of slag remaining after $\mathrm{Zn}$ and $\mathrm{Pb}$ ore processing (Fig. 1). Its topography is rather smooth with a gentle elevation $(\sim 10 \mathrm{~m})$ in the eastern part of the field. These waste rocks originate from the former "Orzeł Biały" Mining and Smelting Company. The dump occupies about $16 \mathrm{ha}$ and is about $20 \mathrm{~m}$ high. There is stored about $3.3 \times 10^{6} \mathrm{~m}^{3}$ wastes (roll-down furnace slags with dolomite 


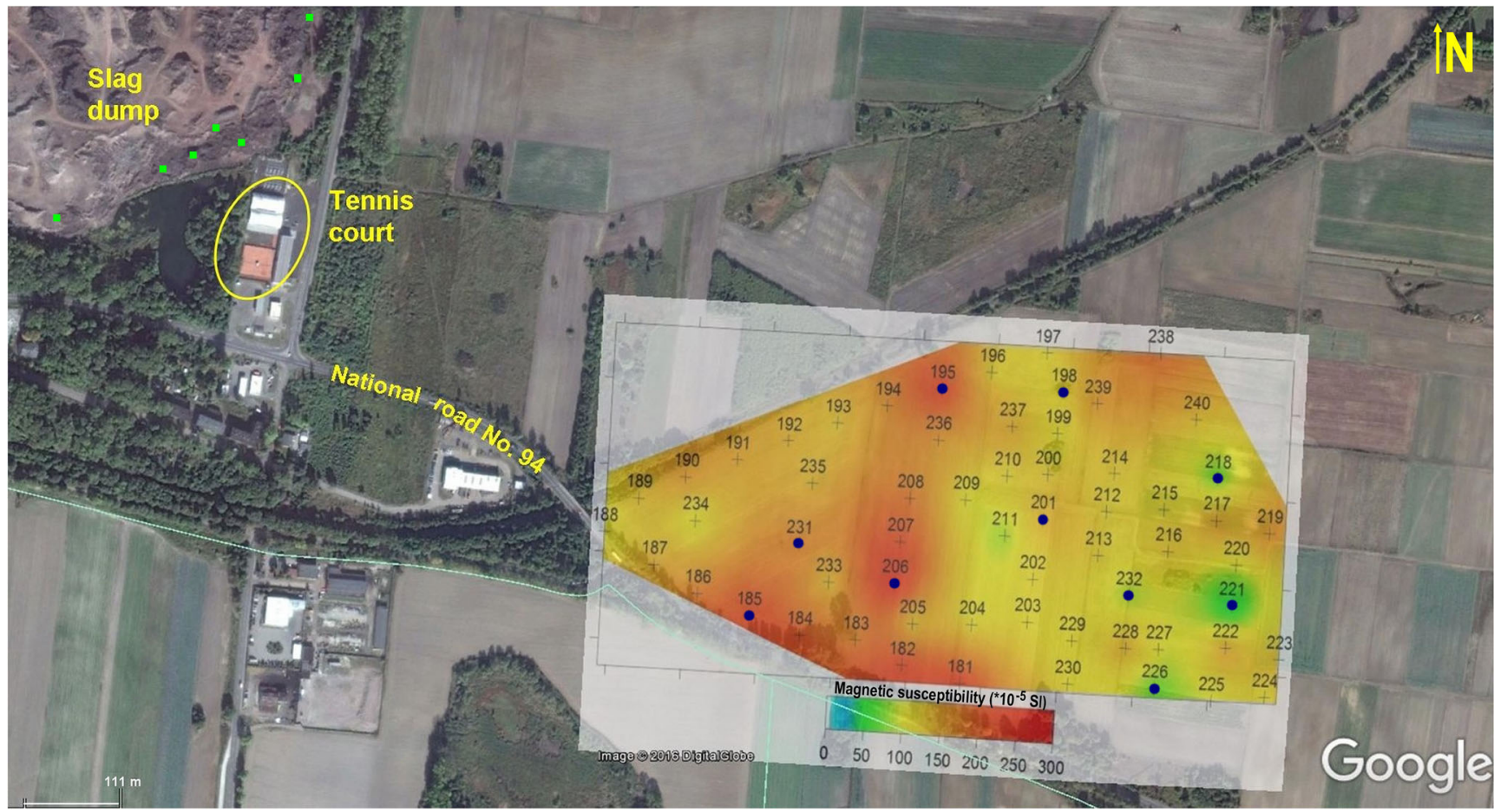

Fig. 1 Study area and spatial distribution of к magnetic susceptibility (source of the base map: (2016 Google Earth). Gray cross — measuring point. Blue dot—core sampling. Green square — slag sampling

debris, agglomerate, and cinders of coke) with a mass of 5 million tons (Ferdyn and Strzyszcz 2002). Currently, the heap has been demolished in order to sell deposited dusts and slags, mainly for road building. For this purpose, a heavy earthmoving plant has been engaged, causing dusting of material rich in metals, especially $\mathrm{Zn}, \mathrm{Pb}$, and $\mathrm{As}$, which content was estimated at the level of $0.26-5.9 \%, 0.03-4.0 \%$, and $0.01-$ $1.0 \%$, respectively (Warchulski et al. 2015).

The soils in this area are rendzinas, developed on Triassic dolomites. They are fertile and were used for agricultural purposes for centuries. The main plants cultivated on this field are vegetables, such as beets, parsley, carrots, celery, etc. The south-western boundary of the studied field is a national road 94 from Zgorzelec (Polish boundary with Germany) to Korczowa (Polish boundary with Ukraine). According to a report of The General Directorate for National Roads and Motorways (GDDKiA 2017), average traffic density on this road is 15,088 vehicles per day (incl. 2346 of heavy duty trucks).

\section{Methods}

\section{Magnetic investigations}

The initial topsoil magnetic survey was performed using magnetic susceptibility meter MS2 Bartington equipped with MS2D loop sensor. At each individual point, the $\mathrm{K}$ value was calculated as a mean value of 11 readings within a square of $2 \mathrm{~m}^{2}$. The $\mathrm{k}$ value was expressed in $10^{-5} \mathrm{SI}$ units. On this area, 60 points of surface magnetic susceptibility measurements were performed. Localization of individual points was confirmed by the Garmin GPS navigation device. Based on the $\mathrm{K}$ measurements, a map of magnetic susceptibility distribution using Surfer 8 software (Golden Software Inc.) was prepared to select the most representative locations for soil sampling. Sampling was performed with application of Humax soil sampler enabling collection of undisturbed $30-\mathrm{cm}$ soil cores. Two twin core samples (taken into plastic tubes at a distance $<1 \mathrm{~m}$ apart) were taken in 10 points at different distances from the pollution source $(0.75,0.9,1.0$, and $1.1 \mathrm{~km})$. Two additional cores were collected close to the road. Registrations of vertical distribution of volume magnetic susceptibility were made at intervals of $1 \mathrm{~cm}$ with application of MS2C Bartington sensor. The vertical distribution of magnetic susceptibility in twin topsoil cores did not always reveal identical shape, and the maximal concentration of TMPs (the layers of maximum $\mathrm{k}$ values) was not at the similar depths; therefore, for further chemical analyses, samples from the uppermost $(0-5 \mathrm{~cm})$ and lower $(5-$ $15 \mathrm{~cm}$ ) parts of arable soil as well as subsoil (below $15 \mathrm{~cm}$ ) were collected. The cores were cut into three parts using a ceramic knife, and subsamples from relevant layers of the twin 
cores were mixed. A Bartington MS2B sensor was used for measurements of low field magnetic susceptibility (K) of samples in order to calculate the mass-specific $(\chi)$ magnetic susceptibility by the following equation:

$\chi=\mathrm{k} / \mathrm{q}\left(\mathrm{m}^{3} \mathrm{~kg}^{-1}\right)$,

where $\mathrm{q}$ is the density of material (Dearing 1994).

\section{Chemical analyses}

Geochemical analyses were carried out at the Department of Chemistry of the Norwegian University of Science and Technology in Trondheim. For determination of PTEs, approximately 200-300 $\mathrm{mg}$ of dried soil sample was weighed into to a bottle containing $9 \mathrm{ml} \mathrm{50 \%} \mathrm{v} / \mathrm{v} \mathrm{HNO}_{3}$. After microwave digestion, each sample was diluted to $108 \mathrm{ml}(109.8 \pm 0.5 \mathrm{~g})$ in Teflon bottle and then transferred to $15 \mathrm{ml} \mathrm{PP-vials.} \mathrm{Concentrations} \mathrm{of} \mathrm{elements} \mathrm{were}$ determined with High-Resolution Inductive Coupled Plasma-Mass Spectrometry (HR-ICP-MS) using an Element 2 instrument from Thermo Electronics. The main concern was on PTE that can migrate with aerosols and particulate matter as well as those expected in deposits (in alphabetical order): Ag, As, Ba, Cd, Cr, Cu, Fe, Ge, Hg, $\mathrm{Mn}, \mathrm{Ni}, \mathrm{Pb}, \mathrm{Se}, \mathrm{Sr}, \mathrm{Tl}, \mathrm{V}$, and $\mathrm{Zn}$.

Additionally, seven samples of materials from the neighboring slag heap were collected to check its influence on the chemical composition of soil from the studied field. Material collected from the heap was divided into two fraction: below $2 \mathrm{~mm}$ (fine fraction) and above $2 \mathrm{~mm}$ (coarse fraction). Magnetic susceptibility measurements were made in both fraction of samples and the corresponding $\chi$ values were calculated. Samples with fine fraction (below $2 \mathrm{~mm}$ ) underwent the same chemical analysis as soil samples taken from the field.

Quality Assurance and Quality Control (QA/QC) was verified against reagent blanks, repeating test, and certified reference material (Soil GBW-07408). Concentrations in the reagent blanks were below detection limits for all elements. Accuracy of the employed procedure was checked by calculating the ratio between analyzed and certified values, and it was estimated at $60-82 \%$ of the certified value for almost all elements, and the confidence uncertainty was below $5 \%$ for $\mathrm{As}, \mathrm{Ba}, \mathrm{Cu}, \mathrm{Fe}, \mathrm{Mn}, \mathrm{Ni}, \mathrm{Pb}, \mathrm{Sr}$, $\mathrm{Tl}, \mathrm{V}$, and $\mathrm{Zn}$; 5-15\% for $\mathrm{Ag}, \mathrm{Cd}, \mathrm{Cr}$, and $\mathrm{Hg}$, while for $\mathrm{Ge}$ and Se, it was above $20 \%$. All results were calculated back to solid material and corrected for blanks.

\section{Calculations and data analysis}

The geoaccumulation index (Igeo) proposed by Müller (1969) defines the soil contamination by a given metal in terms of seven diversified classes. It is defined by the following equation:

$\mathrm{I}_{\text {geo }}=\log _{2}\left(\mathrm{C}_{\mathrm{EL}} / 1.5 \mathrm{C}_{\text {background }}\right)$,

where $\mathrm{C}_{\mathrm{EL}}$ is the element content determined in soil samples, and $\mathrm{C}_{\text {background }}$ is the geochemical background concentration of the metal (Table 1). Factor 1.5 is the correction factor compensating the natural (lithological) fluctuations in the geochemical data. In this case, as the background values of all elements, the mean content calculated from the range of values commonly found in limestone and dolomites given by Kabata-Pendias and Pendias (2001) was applied in calculations of indices. Subsequently, the Tomlinson Pollution Load Index (PLI) was used to assess the overall contamination level of the soil (Tomlinson et al. 1980). Originally, the PLI was applied to assess the estuary pollution using the contents of heavy metals in the algae and flora as the indicators. At present, the PLI is often used to determine how much a set of contaminating elements in a given sample exceeds the background concentration. It also helps to compare the pollution level in places that differ in many aspects (e.g., localization in different climate zones, different industrialization levels, and land development). The PLI is defined as the $n$th root calculated from the product of $n$ contamination factors $\left(\mathrm{CF}_{\mathrm{EL}}\right)$. To calculate the PLI, the following equations were used (Tomlinson et al. 1980):

$$
\begin{aligned}
& \mathrm{CF}_{\mathrm{EL}}=\mathrm{C}_{\mathrm{EL}} / \mathrm{C}_{\text {background }} \\
& \mathrm{PLI}=\left(\mathrm{CF}_{\mathrm{EL} 1} \times \mathrm{CF}_{\mathrm{EL} 2} \times \mathrm{CF}_{\mathrm{EL} 3} \times \ldots . . \times \mathrm{CF}_{\mathrm{ELn}}\right)^{1 / \mathrm{n}}
\end{aligned}
$$

The $\mathrm{CF}_{\mathrm{EL}}$ is the ratio of the content of each heavy metal $\left(\mathrm{C}_{\mathrm{EL}}\right)$ and its background value $\left(\mathrm{C}_{\text {background }}, \mathrm{Tab} .1\right)$. EL1, EL2 ... ELn are the contamination factors for individual pollutants. In the present case, almost all determined elements were involved in the PLI calculation; only elements with Igeo below 1.0 were excluded; therefore, $n=12$ (Ag, As, $\mathrm{Cd}, \mathrm{Co}, \mathrm{Cr}, \mathrm{Cu}, \mathrm{Ge}, \mathrm{Hg}, \mathrm{Pb}, \mathrm{Se}, \mathrm{Tl}$, and $\mathrm{Zn}$ ).

For assessing the human non-cancer health risk posed by individual PTE contained in soil as well as material built the slag heap, a hazard quotient (HQ) was computed as the ratio of the average daily dose of chemical (ADD) to a reference dose (RfD) meaning the maximal tolerable daily intake of an element and established by USEPA (IRIS online database 2016). HQ values were calculated only for those elements with contamination factors exceeding 5.0 (Table 1), i.e., As, $\mathrm{Cd}, \mathrm{Hg}, \mathrm{Pb}, \mathrm{Se}, \mathrm{Tl}$, and $\mathrm{Zn}$. RfDs of these elements were established (Hough et al. 2004; USEPA 2014) as follows: 0.0003, 0.001, 0.0003, 0.035, 
Table 1 Background values (Bkgrd) of elements $\left(\mathrm{mgkg}^{-1}\right)$ commonly found in limestone and dolomites according to Kabata-Pendias and Pendias (2001) as well as contamination factors (CFs) of particular PTE $\left(\mathrm{mgkg}^{-1}\right)$ and Igeo values given as arithmetic mean values of topsoil samples from the whole study area

\begin{tabular}{llllllllllllllllll}
\hline PTE & $\mathrm{Ag}$ & $\mathrm{As}$ & $\mathrm{Ba}$ & $\mathrm{Cd}$ & $\mathrm{Cr}$ & $\mathrm{Cu}$ & $\mathrm{Fe}$ & $\mathrm{Ge}$ & $\mathrm{Hg}$ & $\mathrm{Mn}$ & $\mathrm{Ni}$ & $\mathrm{Pb}$ & $\mathrm{Se}$ & $\mathrm{Sr}$ & $\mathrm{Tl}$ & $\mathrm{V}$ & $\mathrm{Zn}$ \\
\hline Bkgrd & 0.13 & 1.7 & 125 & 0.35 & 10.5 & 6 & 7000 & 0.3 & 0.045 & 600 & 13.5 & 6.5 & 0.065 & 525 & 0.075 & 27.5 & 17.5 \\
$\mathrm{CF}$ & 4.0 & 10.7 & 1.8 & 36.7 & 3.1 & 3.7 & 2.2 & 3.4 & 5.0 & 1.0 & 1.2 & 69.9 & 8.0 & 0.1 & 13.3 & 1.3 & 59.3 \\
Igeo & 1.34 & 2.80 & 0.22 & 7.88 & 1.04 & 1.21 & 0.51 & 1.10 & 1.48 & -0.53 & -0.42 & 5.31 & 2.37 & -4.28 & 3.10 & -0.27 & 5.26 \\
\hline
\end{tabular}

0.005, 0.00001, and $0.3 \mathrm{mg} \mathrm{kg}^{-1} \mathrm{day}^{-1}$ for As, $\mathrm{Cd}, \mathrm{Hg}, \mathrm{Pb}$, $\mathrm{Se}, \mathrm{Tl}$, and $\mathrm{Zn}$, respectively:

$\mathrm{HQ}=\mathrm{ADD} / \mathrm{RfD}$

Given that persons exposed to soil contaminants are mainly farmers cultivating investigated arable fields and workers rebuilding the slag heap, as well as tennis players from the heapneighboring tennis court, the most important exposure pathways were considered to be soil ingestion (incidental consumption of soil on hands or food items), inhalation, and dermal absorption. Therefore, the total ADD of an element consists of totalized doses: from ingestion $\left(\mathrm{ADD}_{\mathrm{I}}\right)$, inhalation $\left(\mathrm{ADD}_{\text {Inh }}\right)$, and dermal absorption $\left(\mathrm{ADD}_{\mathrm{D}}\right)$ which can be calculated according to the following equations (ATSDR 2004; Li et al. 2014; Qing et al. 2015):

$$
\begin{aligned}
& \mathrm{ADD}_{\mathrm{I}}=\left(\mathrm{C} * \mathrm{IR} * \mathrm{EF} * \mathrm{ED}^{*} 10^{-6}\right) /\left(\mathrm{BW}^{*} \mathrm{AT}\right) \\
& \mathrm{ADD}_{\mathrm{Inh}}=\left(\mathrm{C}^{*} \operatorname{Inh} R^{*} \mathrm{EF}^{*} \mathrm{ED}\right) /\left(\mathrm{PEF}^{*} \mathrm{BW}^{*} \mathrm{AT}\right) \\
& \mathrm{ADD}_{\mathrm{D}}=\left(\mathrm{C} * \mathrm{SA} * \mathrm{AF} * \mathrm{BF} * \mathrm{EF}^{*} \mathrm{ED}^{*} 10^{-6}\right) /\left(\mathrm{BW}^{*} \mathrm{AT}\right)
\end{aligned}
$$

All symbols concerning hazard parameters used in Eqs. 7-9 are explained in Table 2. To assess the overall potential noncancer health risk caused by multiple compounds, the hazard index (HI) was introduced as the sum of hazard quotients of individual elements (USEPA 1986). In the present work, HI values were calculated as follows:

$$
\begin{aligned}
\mathrm{HI} & =\Sigma \mathrm{HQ}=\mathrm{ADD}_{\mathrm{As}} / \mathrm{RfD}_{\mathrm{As}}+\mathrm{ADD}_{\mathrm{Cd}} / \mathrm{RfD}_{\mathrm{Cd}} \\
& +\mathrm{ADD}_{\mathrm{Hg}} / \mathrm{RfD}_{\mathrm{Hg}}+\mathrm{ADD}_{\mathrm{Pb}} / \mathrm{RfD}_{\mathrm{Pb}}+\mathrm{ADD}_{\mathrm{Se}} / \mathrm{RfD}_{\mathrm{Se}} \\
& +\mathrm{ADD}_{\mathrm{Tl}} / \mathrm{RfD}_{\mathrm{Tl}}+\mathrm{ADD}_{\mathrm{Zn}} / \mathrm{RfD}_{\mathrm{Zn}}
\end{aligned}
$$

Hazard index values exceeding unity provides evidence that potential health effects may occur. Otherwise $(\mathrm{HI}<1)$, it is assumed that the risk is at an acceptable level.

Moreover, the basic statistical functions of mean, median, standard deviation, Spearman correlation coefficients, and additionally factor analysis were applied (using Statistica 12

\begin{tabular}{|c|c|c|}
\hline Symbol of hazard parameters & Explanation & Assumed value \\
\hline $\mathrm{C}$ & Element content in soil & Specific for each element $\left(\mathrm{mg} \mathrm{kg}^{-1}\right)$ \\
\hline IR & Ingestion rate ${ }^{\mathrm{a}}$ & $100 \mathrm{mg} \mathrm{day}^{-1}$ \\
\hline Inhr & Inhalation rate of soil ${ }^{\mathrm{c}}$ & $12.8 \mathrm{~m}^{3}$ day $^{-1}$ \\
\hline $\mathrm{EF}$ & Exposure frequency ${ }^{\mathrm{b}}$ & 66 days year ${ }^{-1}$ \\
\hline ED & Exposure duration & 20 year \\
\hline BW & Body weight ${ }^{\mathrm{a}}$ & $70 \mathrm{~kg}$ \\
\hline PEF & Particle emission factor $^{\mathrm{c}}$ & $1.36 \times 10^{9} \mathrm{~m}^{3} \mathrm{~kg}^{-1}$ \\
\hline AT & $\begin{array}{l}\text { The period over which the } \\
\text { dose is averaged }\end{array}$ & 365 days $* \mathrm{ED}$ \\
\hline SA & Exposed skin surface area ${ }^{\mathrm{b}}$ & $\begin{array}{l}5700 \mathrm{~cm}^{2} \text { (1/3 of the total skin } \\
\quad \text { surface area) }\end{array}$ \\
\hline $\mathrm{AF}$ & Soil adherence factor ${ }^{\mathrm{b}}$ & $0.07 \mathrm{mg} \mathrm{cm}^{-2}$ day $^{-1}$ \\
\hline $\mathrm{BF}$ & Bioavailability factor $^{\mathrm{a}}$ & 0.1 (unitless) \\
\hline
\end{tabular}
software; StatSoft) in order to analyze and interpret results and explain variations in the data.
Table 2 Hazard parameters used for calculating $\mathrm{ADD}_{\mathrm{I}}, \mathrm{ADD}_{\mathrm{I} \text { nh}}$, and $\mathrm{ADD}_{\mathrm{D}}$
${ }^{\mathrm{a}}$ ATSDR 2004

${ }^{\mathrm{b}}$ Kubicz 2014

${ }^{\mathrm{c}}$ Qing et al. 2015 


\section{Results and discussion}

\section{Magnetic properties}

The preliminary field measurements show that above $80 \%$ of the studied area has $\mathrm{K}$ values exceeding $100 \times 10^{-5}$ SI units. The western part of the studied area, located closer to the waste dump, exhibits higher $\mathrm{K}$ values $\left(98-255 \times 10^{-5} \mathrm{SI}\right.$ units) than the eastern part $\left(27-164 \times 10^{-5} \mathrm{SI}\right.$ units). The highest $\mathrm{K}$ values are observed on the top of the local elevation in the central part of the studied area and along the road (Fig. 1). In addition, several magnetic hot spots related to the local morphology or diversity of soil composition are observed. Magnetic susceptibility map reflects a variation in soil composition and as a proxy for air-derived pollution-its level. There are any rules differentiating the level of magnetic signal responsible for a particular pollution level, but after three decades of application magnetic methods into environmental study, this approach becomes feasible and appropriate. Similar to the assessment of soil pollution caused by PTE, also in the case of magnetic susceptibility, some reference level should be considered. In the case of Piekary where rendzina soils occur, the background level is established as follows: $26.11 \times 10^{-5}$ SI units and $42.16 \times 10^{-8} \mathrm{~m}^{3} \mathrm{~kg}^{-1}$ for $\mathrm{K}$, as well as for $\chi$, respectively (Jordanova 2016). Implementing these background values, the investigated area is characterized by magnetic susceptibility much higher than general background levels $\left(\mathrm{K}_{\text {topsoil }}>27.5\right.$ up to $255.5 \times 10^{-5} \mathrm{SI}$; mean $139 \times 10^{-5}$ SI and $\chi>48$ up to $295 \times 10^{-8} \mathrm{~m}^{3} \mathrm{~kg}^{-1}$; mean $162 \times 10^{-8} \mathrm{~m}^{3} \mathrm{~kg}^{-1}$ ) indicating soil contamination by TMPs.

Vertical distribution of magnetic susceptibility in cores collected from sites 198, 201, 206, 218, and 226 is typical for arable land with homogenized upper soil layers due to plowing (Magiera et al. 2006, 2011b), i.e., in the upper $20 \mathrm{~cm}$, the value of magnetic susceptibility is quite high $\left(50-150 \times 10^{-5} \mathrm{SI}\right.$ units) and stable (Fig. 2), with a distinct drop below $20 \mathrm{~cm}$. Similar trends are observed for magnetic susceptibility along cores from sites 221, 231, and 232 (Fig. 2 ), but with some deviations at $10-15 \mathrm{~cm}$ depth. These cores are characterized by increased $\mathrm{k}$ values in the lower part, reaching values above $250 \times 10^{-5} \mathrm{SI}$ units. In one core from site 185 , a peak with very high $\left(>500 \times 10^{-5}\right.$ SI units $)$ magnetic susceptibility appears at a depth of $5 \mathrm{~cm}$, probably resulted from accidental contamination during plowing. Even in points with the lowest surface values of $\mathrm{k}$ (nos. 218 and 226), below $1-2 \mathrm{~cm}$ of depth, $\mathrm{K}$ rises to a similar level observed at sites with higher magnetic susceptibility at the surface. Such high magnetic signal is not surprising since the $\chi$ of material collected from the slag heap ranged from 3031 to $5857 \times 10^{-8} \mathrm{~m}^{3} \mathrm{~kg}^{-1}$ for fine, easily wind-blown fraction and from 2596 to $6930 \times 10^{-8} \mathrm{~m}^{3} \mathrm{~kg}^{-1}$ for coarse one. The fine fraction of slag material was formed by physical weathering of initial material and was more homogenous than the corresponding coarse-grained fraction. However, the mean and median values of $\chi$ oscillate around $4000 \times 10^{-8} \mathrm{~m}^{3} \mathrm{~kg}^{-1}$, which is a level principally characterizing industrial dusts and wastes (Magiera et al. 2011a).

\section{Geochemical properties}

Soil in the studied area is characterized by neutral soil $\mathrm{pH}$, which is typical for rendzinas, and high concentrations of almost all determined elements. The distributions of some elements correspond closely to the distribution of $\chi$ values (Fig. 3). The highest amounts of $\mathrm{Ag}\left(>0.6 \mathrm{mg} \cdot \mathrm{kg}^{-1}\right)$, As $\left(>20 \mathrm{mg} \cdot \mathrm{kg}^{-1}\right), \mathrm{Ba}\left(>250 \mathrm{mg} \cdot \mathrm{kg}^{-1}\right), \mathrm{Cd}\left(>15 \mathrm{mg} \cdot \mathrm{kg}^{-1}\right), \mathrm{Cu}$ $\left(>30 \mathrm{mg} \cdot \mathrm{kg}^{-1}\right), \mathrm{Ge}\left(>1.5 \mathrm{mg} \cdot \mathrm{kg}^{-1}\right), \mathrm{Hg}\left(>0.3 \mathrm{mg} \cdot \mathrm{kg}^{-1}\right), \mathrm{Ni}$ $\left(>18 \mathrm{mg} \cdot \mathrm{kg}^{-1}\right), \mathrm{Pb}\left(>600 \mathrm{mg} \cdot \mathrm{kg}^{-1}\right), \mathrm{Se}\left(>0.6 \mathrm{mg} \cdot \mathrm{kg}^{-1}\right), \mathrm{Sr}$ $\left(>50 \mathrm{mg} \cdot \mathrm{kg}^{-1}\right), \mathrm{Tl}\left(>1 \mathrm{mg} \cdot \mathrm{kg}^{-1}\right)$, and $\mathrm{Zn}\left(>1200 \mathrm{mg} \cdot \mathrm{kg}^{-1}\right)$ were observed in the western part of the studied area at a distance of $0.75 \mathrm{~km}$ from the source. Chromium and manganese show a stable high concentration through the whole study area, and the content of all the other elements decreases with distance from slag heap - up to $1 \mathrm{~km}$ and then start to increase again in the most elevated sites lying most distant from the source $(1.1 \mathrm{~km}$ distance). The last column on the bar chart (Fig. 3) represents cores sampled close to the road and therefore being influenced mostly by traffic-related emissions, although the impact of secondary emission from a slag dump (about $0.9 \mathrm{~km}$ away from that site) cannot be neglected. It is characterized by enhanced values of $\chi$ as well as contents of $\mathrm{Ag}, \mathrm{As}, \mathrm{Ba}, \mathrm{Cd}, \mathrm{Cu}, \mathrm{Ge}, \mathrm{Hg}, \mathrm{Ni}, \mathrm{Pb}, \mathrm{Se}, \mathrm{Tl}$, and $\mathrm{Zn}$.

According to the limit values proposed by regulations from Swiss Agency for the Environment, Forests, and Landscape, based on nitric acid extraction (Desaules et al. 2001), contents of $\mathrm{Zn}, \mathrm{Pb}$, and $\mathrm{Cd}$ in all investigated samples (except subsoil at site no. 185) exceed threshold values for arable soils (150; 50 and $0.8 \mathrm{mg} \mathrm{kg}^{-1}$, respectively). The contents of barium and arsenic are also relatively high, but these elements are not considered in the above regulations. Similar to the magnetic results, an effect of plowing is observed in the PTE content. Level of elements is similar at different depths $(0-5$ and 5 $15 \mathrm{~cm}$ ) due to mixing of soil horizons during agricultural treatment. Only in case of profiles lying farther from the slag dump (1-1.1 km), as well as soil profile influenced by traffic, PTE content in the deeper layers is definitely lower. Contents of $\mathrm{Cr}, \mathrm{Fe}, \mathrm{Mn}$, and $\mathrm{V}$ are relatively evenly distributed, independent of the distance from the slag dump as well as the soil horizon. Such a distribution can be explained not only by agriculture treatment but also by geological background and leaching processes downwards the soil profile (Degryse and Smolders 2006). In general, however, enhanced concentrations of most PTE are observed at $0-15 \mathrm{~cm}$ depth, decreasing toward the bottom end. This may point at the influence of anthropogenic activity in this region and especially re-suspension from adjacent smelting slag heap characterized 
Magnetic susceptibility $\left(\mathrm{K} \times 10^{-5} \mathrm{SI}\right)$
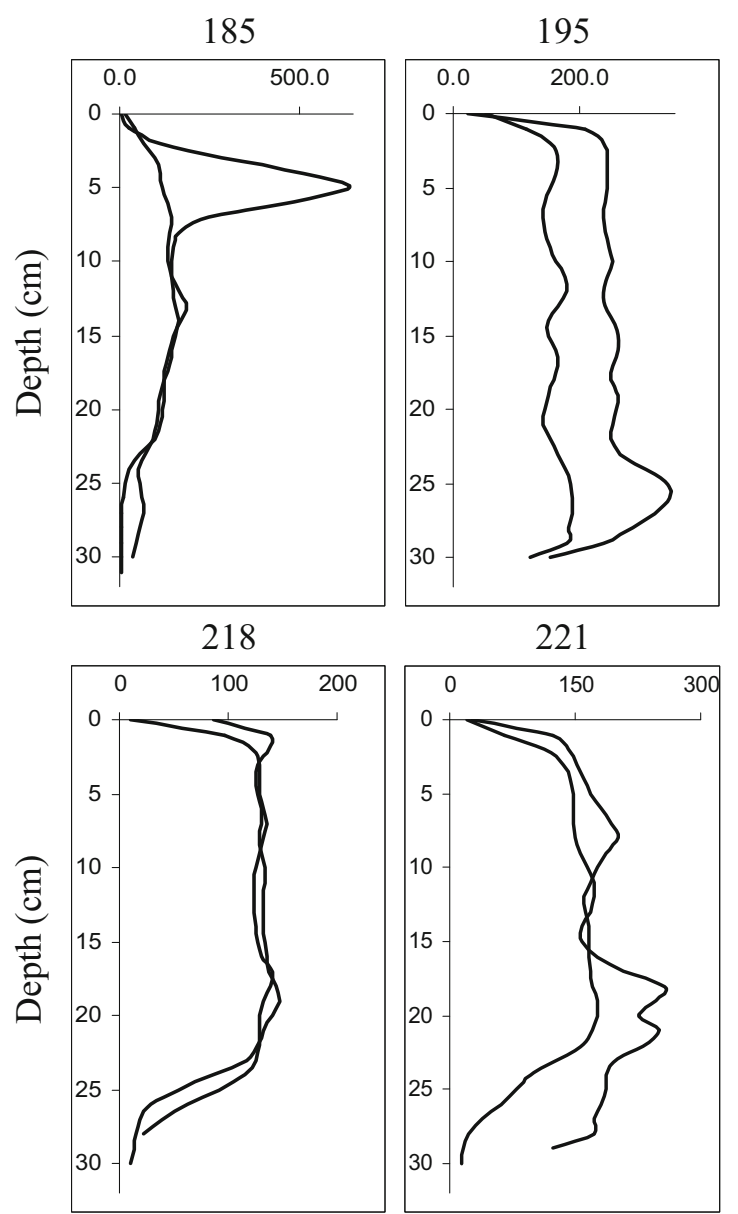

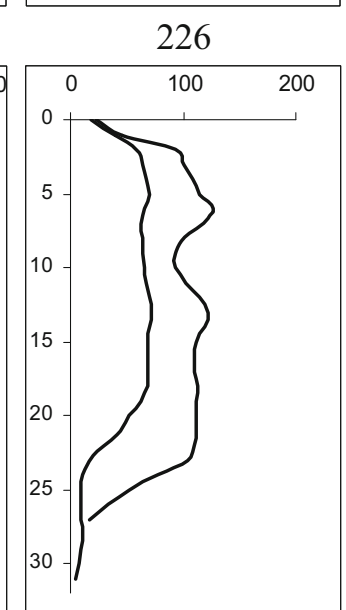

198

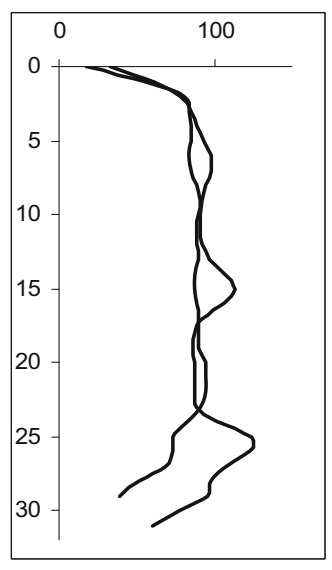

201

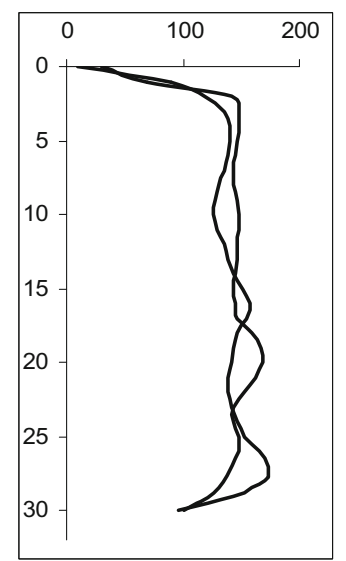

231

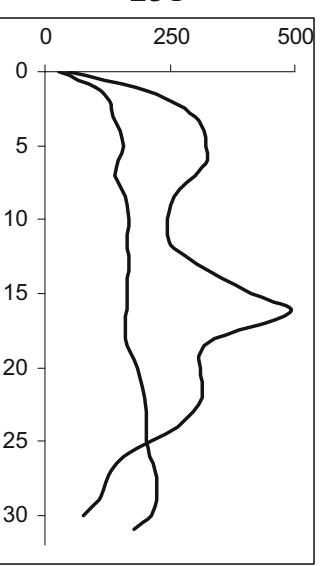

206

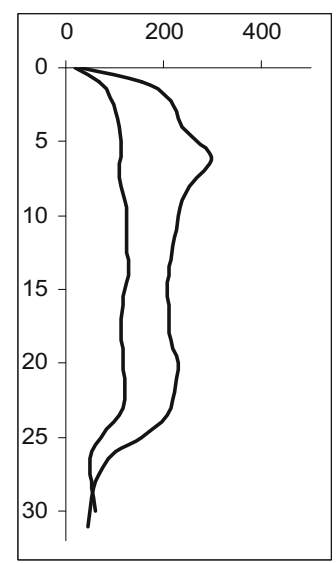

232

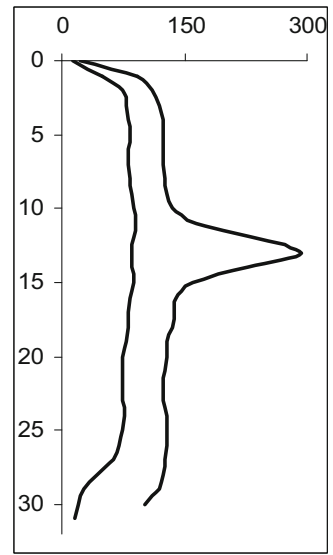

Fig. 2 Vertical distribution of magnetic susceptibility ( $\kappa)$ in soil profiles from the study area $(198,201,206,218$ - typical distribution of arable soil profiles; 195, 221 - distribution of arable soil profiles with some

by very high values of magnetic susceptibility ( $\chi$ above $\left.2500 \times 10^{-8} \mathrm{~m}^{3} \mathrm{~kg}^{-1}\right)$. The rich chemical composition of dumped wastes is strongly dominated by $\mathrm{Fe}, \mathrm{Zn}, \mathrm{Pb}, \mathrm{As}$, $\mathrm{Mn}$, and $\mathrm{Cu}$; $\mathrm{Ba}, \mathrm{Ni}, \mathrm{Cr}, \mathrm{Cd}$, and $\mathrm{Tl}$ have enhanced contents as well, while the content of Se is below detection limit (Table 3).

\section{Soil pollution source apportionment}

Results of factor analysis confirm two different sources of element load in the topsoil and subsoil as well (Table 4). The first factor (explaining 70 and $83 \%$ of the variance for topsoil and subsoil, respectively) combines magnetic susceptibility and PLI as well as most individual elements (Ag, As, Ba, Cd, Co, Cu, Fe, Ge, Hg, Ni, Se, Sr, Tl, and $\mathrm{Zn}$ ), i.e., variables mainly connected with the composition of the slag heap. The second factor (16 and 10\% of the variance for topsoil and subsoil, respectively) comprises mainly $\mathrm{Cr}, \mathrm{Pb}$, and $\mathrm{V}$, which may all be connected with traffic-related emissions: $\mathrm{Cr}$ can originate from brake increase in $\mathrm{K}$ in deeper layers; 185, 226, 231, 232-varied distribution of soil profiles with distinct peaks of $\kappa$ values)

linings, engine oils, fuel, and road abrasion (Wiseman et al. 2015; Wang et al. 2017), while Pb and V (as well as Ni and Cd) - from pipe emissions and heavy fuel oil combustion of both gasoline and diesel engines (Wilhelm et al. 2012; Çolak et al. 2016). Additional important source of $\mathrm{Pb}$ was wear abrasion or also earlier depositions (as $\mathrm{Pb}$ was present in petrol in Poland until 2005) (Wawer et al. 2017). Moreover, taking into consideration that the investigated area is intensively utilized for agricultural production, the fields were most likely fertilized in order to yield heavier crops. As a consequence, continued long-term fertilization can increase soil metal contents or their bioavailability, even when these occur at low concentrations (Leita et al. 1999).

As enhanced magnetic susceptibility indicated soil contamination caused by air-derived particulate matter, the significant relationships between magnetic susceptibility (related to the amount of TMPs being the carriers of heavy metals) and content of particular PTE can be considered as an indicator pointed at a similar source of pollution (Zawadzki et al. 2015; Lu et al. 2016; Bourliva 



Fig. 3 Distribution of PTE (in $\mathrm{mg} \mathrm{kg}^{-1}$ ) presented in alphabetical order: $\mathrm{Ag}, \mathrm{As}, \mathrm{Ba}, \mathrm{Cd}, \mathrm{Cr}, \mathrm{Cu}, \mathrm{Fe}, \mathrm{Ge}, \mathrm{Hg}, \mathrm{Mn}, \mathrm{Ni}, \mathrm{Pb}, \mathrm{Se}, \mathrm{Sr}, \mathrm{Tl}, \mathrm{V}$, and $\mathrm{Zn}$ and the mass-specific magnetic susceptibility values $\left(\chi \times 10^{-8} \mathrm{~m}^{3} \mathrm{~kg}^{-1}\right)$ in different soil horizons (upper 0-5 cm; medium 5-15 cm; bottom below

$15 \mathrm{~cm}$ ) according to increasing distance from the metallurgical slag dump. The last bar represents samples collected close to the road at a distance of $\sim 0.9 \mathrm{~km}$

et al. 2017). In this study, significant and relatively high correlation coefficients (0.61-0.97, Table 5) were observed for topsoil in the case of $\mathrm{Ag}, \mathrm{As}, \mathrm{Ba}, \mathrm{Cd}, \mathrm{Co}, \mathrm{Cu}, \mathrm{Fe}, \mathrm{Ge}$, $\mathrm{Hg}$, Ni, Se, Sr, Tl, and $\mathrm{Zn}$, which all may be related to past and present pollution sources. A similar relationship is noticed for PLI as well as between PLI and the same, abovementioned PTE, suggesting re-suspension from the adjacent metallurgical slag dump as the main source of elevated contents of PTE and enhanced $\chi$. Obviously, the nearby busy road and several small enterprises may also have contaminated the studied soils. Undoubtedly, the lithology of this area (ore-bearing dolomites) has a significant effect on its geochemistry. Negative results of Igeo demonstrate background concentrations; therefore, $\mathrm{Mn}, \mathrm{Ni}, \mathrm{Sr}$, and $\mathrm{V}$, as well as $\mathrm{Ba}$ (with Igeo $\sim 0.2$ ), can be considered as elements originated from geological background.

\section{Assessment of soil contamination}

While assessing soil contamination, the results should be compared with the so-called reference level which can be understood as a background value or some acceptable threshold value above which an environmental or human health hazard can occur (Reimann and de Caritat 2005; Gałuszka 2007; Desaules 2012). Such a comparative method is the PLI, often used for more complex comparison between different geographic sites (e.g., Rachwał et al. 2015), but in the present case, its spatial distribution reflects the extent of contamination in a better way than contents of individual elements. The highest PLI values occur in the north-western part of the field, decreasing in the south-east direction; hence, the PLI map indicates unequivocally the re-suspension from the adjacent smelting slag dump as the main source of soil contamination 

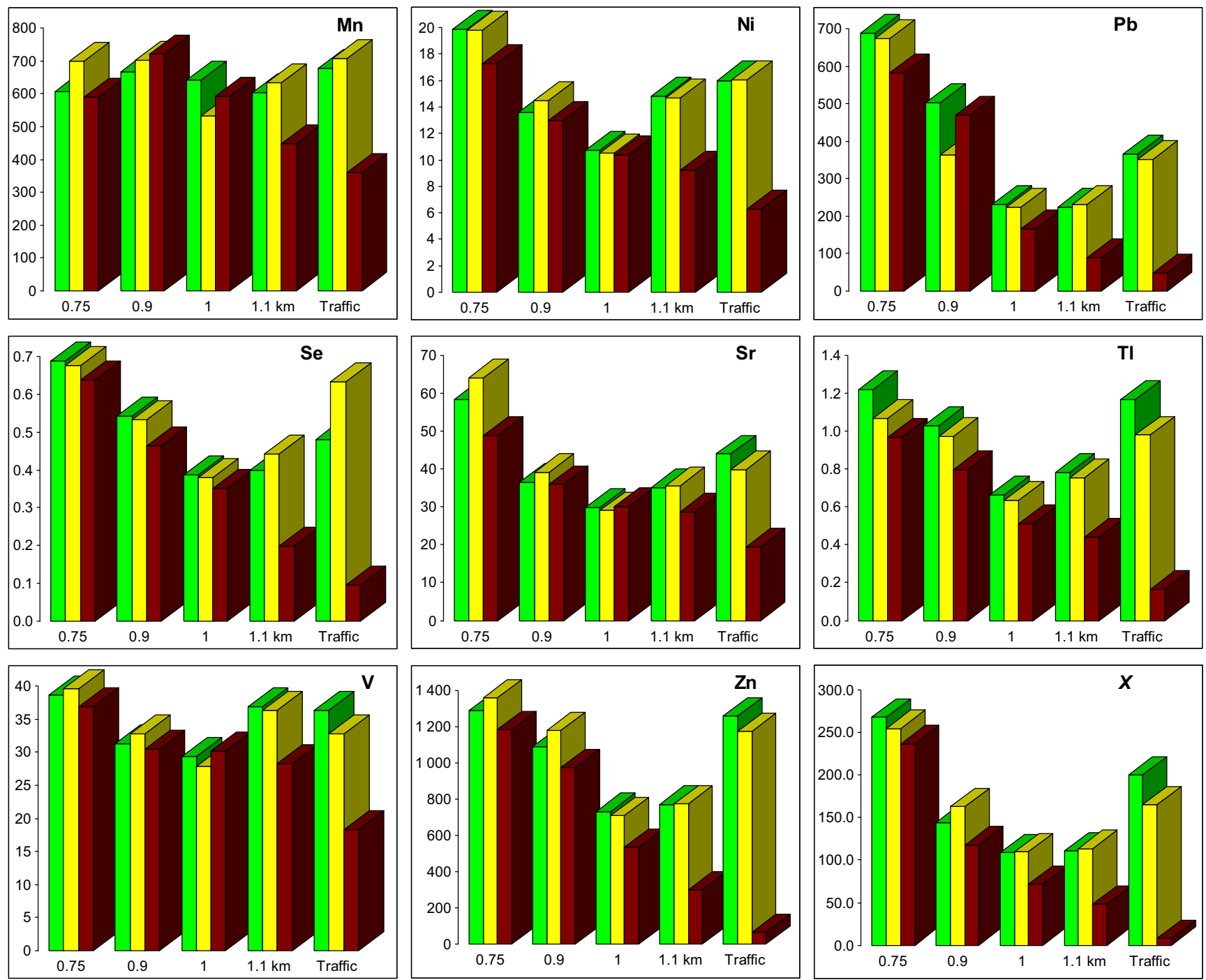

Legend: $\square$ upper

medium

bottom

Fig. 3 (continued)

by PTE (Fig. 4). Nevertheless, the soil magnetic susceptibility distribution signifies an additional source of contamination in the southern part of the field, next to national road no. 94 (Figs. 4 and 5). According to PLI classification (Tomlinson et al. 1980), the obtained results describe the topsoil of the whole area as extremely heavily polluted (PLI $>3$ ), although with a distinct difference between the more distant eastern $(6.4<$ PLI $<9.3)$ and the closer to slag dump western part of

Table 3 Statistics concerning content of individual PTE $\left(\mathrm{mgkg}^{-1}\right)$ as well as mass-specific magnetic susceptibility $\left(10^{-8} \mathrm{~m}^{3} \mathrm{~kg}^{-1}\right)$ in the material collected from smelting slag heap (Se-below detection limit)

\begin{tabular}{llllllllrrrrr}
\hline & As & $\mathrm{Ba}$ & $\mathrm{Cd}$ & $\mathrm{Cr}$ & $\mathrm{Cu}$ & $\mathrm{Fe}$ & $\mathrm{Mn}$ & $\mathrm{Ni}$ & $\mathrm{Pb}$ & $\mathrm{Tl}$ & $\mathrm{Zn}$ & $\chi$ \\
\hline Min & 1579 & 324 & 3 & 27 & 2877 & 44,800 & 2320 & 123 & 2968 & 0 & 8483 & 3031 \\
Max & 9692 & 655 & 101 & 59 & 8784 & 119,400 & 10,727 & 307 & 9456 & 129 & 37,083 & 5857 \\
Ave. & $\mathbf{5 2 6 4}$ & $\mathbf{5 3 1}$ & $\mathbf{2 6}$ & $\mathbf{4 5}$ & $\mathbf{4 7 5 2}$ & $\mathbf{8 0 , 4 0 0}$ & $\mathbf{4 9 3 5}$ & $\mathbf{1 8 6}$ & $\mathbf{6 1 4 4}$ & $\mathbf{2 6}$ & $\mathbf{1 5 , 4 7 6}$ & $\mathbf{4 1 7 7}$ \\
Med. & $\mathbf{4 7 2 0}$ & $\mathbf{5 6 7}$ & $\mathbf{1 6}$ & $\mathbf{4 5}$ & $\mathbf{3 6 1 8}$ & $\mathbf{8 1 , 1 0 0}$ & $\mathbf{3 6 8 4}$ & $\mathbf{1 7 0}$ & $\mathbf{7 0 7 2}$ & $\mathbf{2 6}$ & $\mathbf{1 2 , 9 0 9}$ & $\mathbf{4 0 8 5}$ \\
St. Dev. & 2446 & 128 & 32 & 9 & 2272 & 23,700 & 2765 & 60 & 2382 & 39 & 9075 & 952 \\
\hline
\end{tabular}

Bold entries indicate only the lines with mean and median values 
Table 4 Results of factor analysis of the data variability for topsoil (0$5 \mathrm{~cm}$ ) and subsoil (below $15 \mathrm{~cm}$ )

\begin{tabular}{|c|c|c|c|c|}
\hline \multirow[t]{2}{*}{ Element } & \multicolumn{2}{|l|}{ Topsoil } & \multicolumn{2}{|l|}{ Subsoil } \\
\hline & $\mathrm{F} 1$ & $\mathrm{~F} 2$ & $\mathrm{~F} 1$ & $\mathrm{~F} 2$ \\
\hline $\mathrm{Ag}$ & -0.79 & & -0.92 & \\
\hline As & -0.92 & & -0.98 & \\
\hline $\mathrm{Ba}$ & -0.97 & & -0.99 & \\
\hline $\mathrm{Cd}$ & -0.85 & & -0.92 & \\
\hline Co & -0.87 & & -0.88 & \\
\hline $\mathrm{Cr}$ & & 0.75 & -0.75 & 0.58 \\
\hline $\mathrm{Cu}$ & -0.99 & & -0.997 & \\
\hline $\mathrm{Fe}$ & -0.77 & & -0.84 & \\
\hline $\mathrm{Ge}$ & -0.96 & & -0.97 & \\
\hline $\mathrm{Hg}$ & -0.97 & & -0.88 & \\
\hline $\mathrm{Mn}$ & & & -0.64 & \\
\hline $\mathrm{Ni}$ & -0.88 & & -0.95 & \\
\hline $\mathrm{Pb}$ & & -0.75 & -0.74 & -0.60 \\
\hline $\mathrm{Se}$ & -0.93 & & -0.98 & \\
\hline $\mathrm{Sr}$ & -0.94 & & -0.97 & \\
\hline $\mathrm{Tl}$ & -0.94 & & -0.97 & \\
\hline $\mathrm{V}$ & & 0.74 & -0.82 & 0.54 \\
\hline $\mathrm{Zn}$ & -0.93 & & -0.96 & \\
\hline MS & -0.95 & & -0.96 & \\
\hline PLI & -0.84 & & -0.98 & \\
\hline Variance explained (\%) & 70 & 16 & 83 & 10 \\
\hline
\end{tabular}

$M S$ mass-specific magnetic susceptibility, $P L I$ pollution load index the area exhibiting higher level of pollution $(9.4<\mathrm{PLI}<12.3)$ (Fig. 4). The PLI decreases slightly with the depth, especially at most distant sites. In the case of the sampling points located closer to the dump, increase in PLI at the medium level of soil profiles $(5-15 \mathrm{~cm})$ is stated. It can be explained by agrotechnical treatments as well as by leaching of some elements into deeper soil horizons.

Diversified results of Igeo reveal that in the Piekary area, the entire soil profiles are extremely contaminated by $\mathrm{Cd}, \mathrm{Zn}$, and $\mathrm{Pb}(4.5<$ mean Igeo $<8)$ followed by $\mathrm{As}$, Se, and $\mathrm{Tl}$ $(2<$ mean Igeo < 3.2) which, according to Müller's classification (1969), exhibit the third Igeo class, i.e., moderately to strongly contaminated (Table 1). In contrast, $\mathrm{Ba}, \mathrm{Fe}, \mathrm{Mn}, \mathrm{Ni}$, $\mathrm{Sr}$, and $\mathrm{V}$ are characterized by very low values of Igeo in all soil horizons suggesting no contamination, or in case of $\mathrm{Ba}$ and $\mathrm{Fe}(0.3<$ mean Igeo $<0.56)$ uncontaminated or moderately contaminated soil (Müller 1969).

\section{Assessment of human health risk}

Although the study area is known for the significant contamination caused by non-ferrous metallurgy as well as dumping of the smelting slags and processing wastes (Rybicka 1996; Ullrich et al. 1999; Kulka and Gzyl 2008), the fields are kept cultivated for food production (e.g., cabbage, onion, cauliflower), regardless of the possible health risk posed by consumption of local vegetables. Heavy metals, such as $\mathrm{Cd}, \mathrm{Hg}$, $\mathrm{Cr}, \mathrm{Pb}$, and $\mathrm{As}$, can be easily transferred from soil to leaf

Table 5 Correlation matrix of investigated elements for topsoil $(n=12$; correlation coefficients in bold are significant with $p<0.05)$

\begin{tabular}{|c|c|c|c|c|c|c|c|c|c|c|c|c|c|c|c|c|c|c|c|}
\hline & $\mathrm{Ag}$ & & & & & & & & & & & & & & & & & & \\
\hline As & 0.84 & As & & & & & & & & & & & & & & & & & \\
\hline $\mathrm{Ba}$ & 0.74 & 0.84 & $\mathrm{Ba}$ & & & & & & & & & & & & & & & & \\
\hline $\mathrm{Cd}$ & 0.85 & 0.91 & 0.82 & $\mathrm{Cd}$ & & & & & & & & & & & & & & & \\
\hline Co & 0.43 & 0.67 & 0.88 & 0.62 & Co & & & & & & & & & & & & & & \\
\hline $\mathrm{Cr}$ & 0.15 & 0.41 & 0.55 & 0.19 & 0.76 & $\mathrm{Cr}$ & & & & & & & & & & & & & \\
\hline $\mathrm{Cu}$ & 0.77 & 0.88 & 0.97 & 0.83 & 0.85 & 0.56 & $\mathrm{Cu}$ & & & & & & & & & & & & \\
\hline $\mathrm{Fe}$ & 0.31 & 0.64 & 0.72 & 0.39 & 0.86 & 0.90 & 0.75 & $\mathrm{Fe}$ & & & & & & & & & & & \\
\hline $\mathrm{Ge}$ & 0.72 & 0.80 & 0.98 & 0.83 & 0.90 & 0.55 & 0.96 & 0.69 & $\mathrm{Ge}$ & & & & & & & & & & \\
\hline $\mathrm{Hg}$ & 0.80 & 0.87 & 0.93 & 0.85 & 0.86 & 0.51 & 0.95 & 0.70 & 0.95 & $\mathrm{Hg}$ & & & & & & & & & \\
\hline $\mathrm{Mn}$ & 0.16 & 0.38 & -0.05 & 0.38 & -0.09 & -0.15 & 0.01 & -0.07 & -0.09 & 0.01 & $\mathrm{Mn}$ & & & & & & & & \\
\hline $\mathrm{Ni}$ & 0.51 & 0.72 & 0.86 & 0.52 & 0.91 & 0.82 & 0.87 & 0.95 & 0.84 & 0.84 & -0.19 & $\mathrm{Ni}$ & & & & & & & \\
\hline $\mathrm{Pb}$ & 0.65 & 0.30 & 0.24 & 0.41 & -0.10 & -0.39 & 0.31 & -0.22 & 0.22 & 0.34 & 0.04 & -0.01 & $\mathrm{~Pb}$ & & & & & & \\
\hline $\mathrm{Se}$ & 0.80 & 0.92 & 0.90 & 0.88 & 0.80 & 0.41 & 0.87 & 0.63 & 0.87 & 0.92 & 0.26 & 0.75 & 0.28 & $\mathrm{Se}$ & & & & & \\
\hline $\mathrm{Sr}$ & 0.69 & 0.82 & 0.89 & 0.74 & 0.82 & 0.55 & 0.95 & 0.76 & 0.89 & 0.92 & 0.04 & 0.85 & 0.40 & 0.82 & $\mathrm{Sr}$ & & & & \\
\hline $\mathrm{Tl}$ & 0.87 & 0.93 & 0.90 & 0.89 & 0.72 & 0.47 & 0.91 & 0.64 & 0.88 & 0.91 & 0.11 & 0.76 & 0.28 & 0.88 & 0.79 & $\mathrm{Tl}$ & & & \\
\hline $\mathrm{V}$ & 0.17 & 0.47 & 0.56 & 0.18 & 0.76 & 0.96 & 0.58 & 0.96 & 0.53 & 0.55 & -0.13 & 0.88 & -0.33 & 0.46 & 0.61 & 0.49 & $\mathrm{~V}$ & & \\
\hline $\mathrm{Zn}$ & 0.88 & 0.95 & 0.90 & 0.95 & 0.69 & 0.40 & 0.92 & 0.56 & 0.88 & 0.88 & 0.28 & 0.68 & 0.35 & 0.89 & 0.82 & 0.95 & 0.39 & $\mathrm{Zn}$ & \\
\hline$\chi$ & 0.76 & 0.84 & 0.95 & 0.88 & 0.81 & 0.37 & 0.97 & 0.61 & 0.96 & 0.94 & 0.00 & 0.77 & 0.39 & 0.87 & 0.91 & 0.87 & 0.41 & 0.89 & $x$ \\
\hline PLI & 0.74 & 0.77 & 0.85 & 0.77 & 0.65 & 0.25 & 0.85 & 0.50 & 0.83 & 0.80 & -0.01 & 0.66 & 0.43 & 0.78 & 0.82 & 0.76 & 0.30 & 0.82 & 0.87 \\
\hline
\end{tabular}




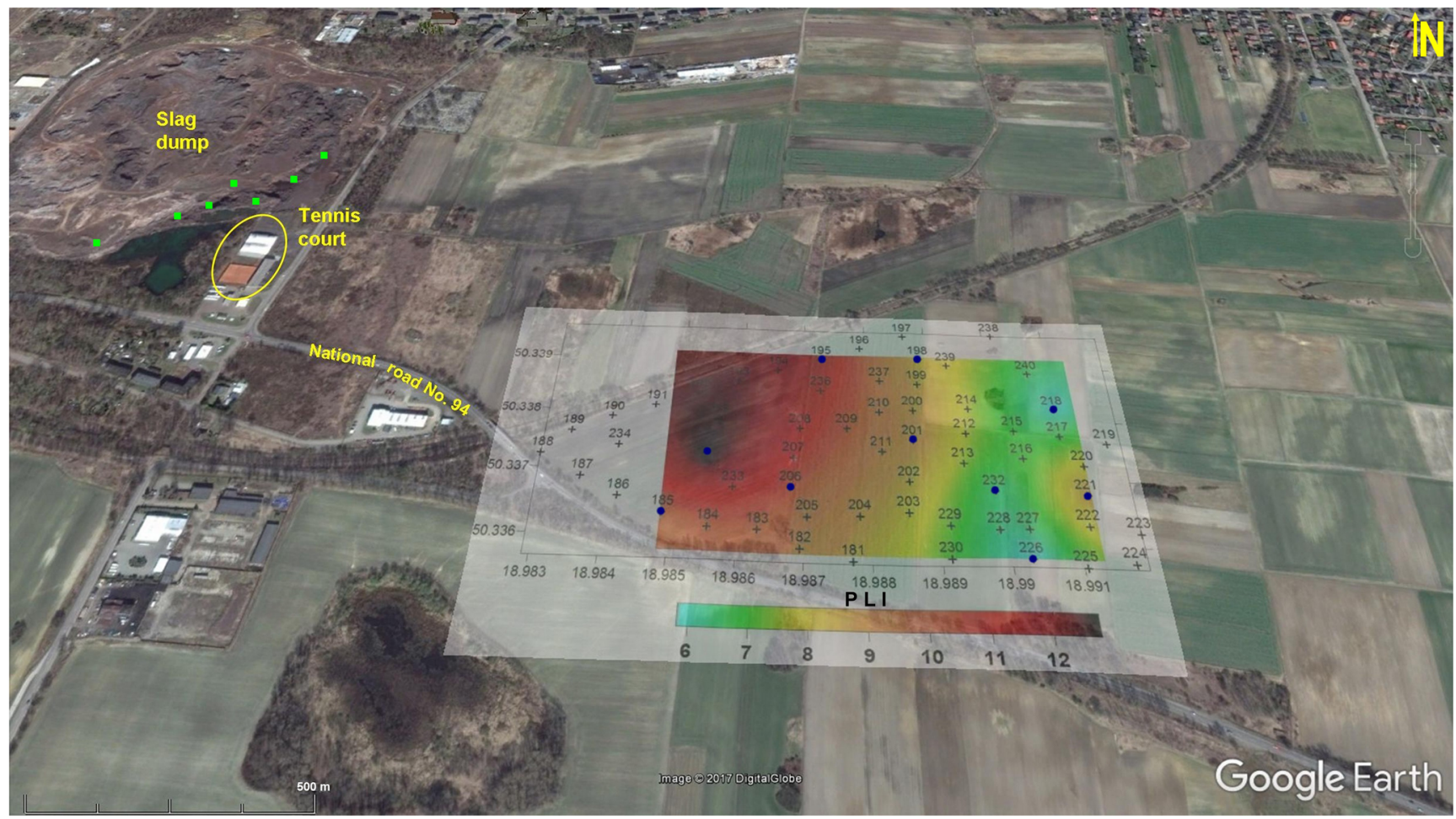

Fig. 4 The spatial distribution of PLI in the topsoil $(0-5 \mathrm{~cm})$ of the area of study (source of the base map: (92016 Google Earth); gray cross- measuring point, blue dot — core sampling, green square — slag sampling

vegetables (Liu et al. 2013; Chang et al. 2014). The pollutants can enter human bodies through three pathways: oral ingestion, dermal contact, and inhalation of soil and dust particles.

The potential human non-cancer health risk is assessed by means of HQ and HI (Table 6). The order of HQ for particular elements is as follows: $\mathrm{Tl}>\mathrm{As}>\mathrm{Pb}=\mathrm{Cd}>\mathrm{Zn}>\mathrm{Hg}>\mathrm{Se}$ for the cultivated field and $\mathrm{As}>\mathrm{Tl}>\mathrm{Pb}>\mathrm{Zn}>\mathrm{Cd}$ for slag heap. For the field, the HI does not exceed unity; therefore, deleterious effect for farmers should not occur.

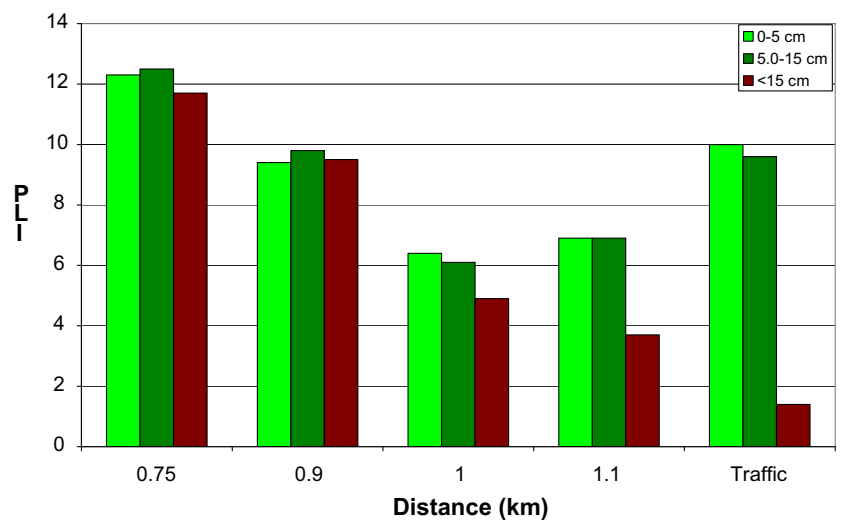

Fig. 5 PLI values of soil (from different depths $0-5,5-15$, and $<15 \mathrm{~cm}$ ) from the study sites ordered according to the increasing distance from metallurgical slag dump calculated on the basis of 11 elements. The last column represents samples collected close to the road
Surprisingly, our research estimates the non-cancer hazard index at a level below unity, demonstrating no adverse health effect to the residents, especially those working in the arable field. It should be pointed out that in HI, computing the dietary intake was not taken into consideration; therefore, the health risk for field workers will increase due to consumption of crops. Unfortunately, the industrial workers rebuilding the slag dump are seriously endangered by PTE occurring in the dumped material because the $\mathrm{HI}$ is extremely high and equals almost 74, the risk is enhanced by the fact that As and $\mathrm{Tl}$, both very toxic elements, are the main contributors

Table 6 HQs of individual heavy metals and HIs for the area of study

\begin{tabular}{llll}
\hline & Whole area & Site no. 195 & Slag heap \\
\hline $\mathrm{As}$ & 0.22 & 0.26 & 63.41 \\
$\mathrm{Cd}$ & 0.05 & 0.06 & 0.09 \\
$\mathrm{Hg}$ & 0.0027 & 0.0038 & - \\
$\mathrm{Pb}$ & 0.05 & 0.12 & 0.63 \\
$\mathrm{Se}$ & 0.0004 & 0.0005 & - \\
$\mathrm{Tl}$ & 0.36 & 0.38 & 9.36 \\
$\mathrm{Zn}$ & 0.01 & 0.01 & 0.19 \\
$\mathbf{H I}$ & $\mathbf{0 . 6 9 3}$ & $\mathbf{0 . 8 3 4}$ & $\mathbf{7 3 . 6 8}$
\end{tabular}

Bold entries indicate only the lines with $\mathrm{HI}$ values as a target of calculations 
for this value. Moreover, right at the foot of the dump, a tennis court is located, posing some potential health risk for the tennis players, especially in windy weather. Still, comparing the present data with other similar studies, the overall health threat appears to be quite low. For example, Bourliva et al. (2017) stated that in an industrial area near Thessaloniki hazard quotient contributed by $\mathrm{Pb}$ alone exceeded 10 . Similarly, in the most important mining and metallurgical centers in Spain, HI amounted to 9.3 with arsenic as the main component (Wcisło et al. 2016). In the Piekary area, the highest contribution to HI was provided by As together with $\mathrm{Tl}$, both possessing highly toxic and carcinogenic properties (Wierzbicka et al. 2004; Rieuwerts et al. 2006; Núñez et al. 2016).

\section{Conclusions}

The results reported show that an integrated two-stage geophysical/geochemical method provides straightforward estimates of soil pollution, which together with application of pollution and health hazard indices can be used for assessment of soil contamination and the human health risk of PTE transported by the air from the local source of pollution and deposited on the cultivated soil layer. The investigations pointed out that soils in the vicinity of the metallurgical slag dump in Piekary are heavily polluted. Spatial distribution of magnetic susceptibility pointed at local "pollution hotspots," while PLI reflected the general trend in distribution of PTE. Proper geophysical and geochemical data interpretation supported by statistical principal component analysis enabled identification of at least three different sources of pollution including metallurgical slug dump as a main source, but also traffic pollution influencing the area located along a busy road and relatively strong influence from the geochemical background. The latter source was related to the layer of weathered dolomites present in the background rock, which enriched the subsoil in elements such as $\mathrm{Ba}, \mathrm{Mn}, \mathrm{Ni}, \mathrm{Sr}$, and $\mathrm{V}$. In spite of the relatively high geochemical background, the correlations in topsoil between magnetic susceptibility and contents of anthropogenically derived PTE were high $(>0.8)$ for such elements such as $\mathrm{As}, \mathrm{Ba}, \mathrm{Cd}, \mathrm{Co}, \mathrm{Cu}, \mathrm{Ge}, \mathrm{Hg}, \mathrm{Se}, \mathrm{Sr}, \mathrm{Tl}$, and $\mathrm{Zn}$. In the light of present results concerning soil contamination, long lasting and regularly farming of these fields may pose a real threat to human health. Therefore, health hazard index was computed, but it revealed no adverse health effect to the farmers cultivating arable soil (HI below 1). However, the high health risk $(\mathrm{HI} \sim 74)$ occurred in the direct vicinity of dusting slag dump, caused by very toxic elements as As and Tl. Unquestionably, the investigated area is highly polluted and may pose a human health threat. Therefore, regardless of the present results, more detailed site surveys (involving air, soil, water, and consumable plants and crops) should always be required when assessing a specific site within an urban area with agriculture land use. Further investigations should be focused on contribution of different sources to the heavy metal pollution in soil-crop systems in this area. A site-specific approach should be used to redevelop this kind of area in order to reduce ecological and human health hazard.

Acknowledgements This study was part of the IMPACT project entitled "Development of integrated geophysical/geochemical methods of soil and groundwater pollution assessment and control in problematic areas," receiving funding from the Polish-Norwegian Research program operated by the National Center for R\&D under the Norwegian Financial mechanism 2009-2014 in the framework of Project Contract No. PolNor/199338/45/2013.

Open Access This article is distributed under the terms of the Creative Commons Attribution 4.0 International License (http:// creativecommons.org/licenses/by/4.0/), which permits unrestricted use, distribution, and reproduction in any medium, provided you give appropriate credit to the original author(s) and the source, provide a link to the Creative Commons license, and indicate if changes were made.

\section{References}

Agency for Toxic Substances and Disease Registry (ATSDR) (2004) Public health assessment guidance manual. Appendix G: calculating exposure doses. https://www.atsdr.cdc.gov/publications_hac.html

Baran A, Wieczorek J (2015) Application of geochemical and ecotoxicity indices for assessment of heavy metals content in soils. Arch Environ Prot 41(2):54-63. https://doi.org/10.1515/aep-2015-0019

Beckwith PR, Ellis JB, Revitt DM (1986) Heavy metal and magnetic relationships for urban source sediments. Phys Earth Planet Inter 42:67-75. https://doi.org/10.1016/S0031-9201(86)80009-7

Bourliva A, Papadopoulou L, Aidona E, Giouri K, Simeonidis K, Vourlias G (2017) Characterization and geochemistry of technogenic magnetic particles (TMPs) in contaminated industrial soils: assessing health risk via ingestion. Geoderma 295:86-97. https://doi.org/10.1016/j.geoderma.2017.02.001

Cabała J, Żogała B, Dubiel R (2008) Geochemical and geophysical study of historical $\mathrm{Zn}-\mathrm{Pb}$ ore processing waste dump areas (southern Poland). Polish J Environ Stud 17(5):693-700

Cao L, Appel E, Hu S, Yin G, Lin H, Rösler W (2015) Magnetic response to air pollution recorded by soil and dust-loaded leaves in a changing industrial environment. Atmos Environ 119:304-313. https://doi. org/10.1016/j.atmosenv.2015.06.017

Chang CY, Yu HY, Chen JJ, Li FB, Zhang HH, Liu CP (2014) Accumulation of heavy metals in leaf vegetables from agricultural soils and associated potential health risks in the Pearl River Delta, South China. Environ Monit Assess 186(3):1547-1560. https://doi. org/10.1007/s10661-013-3472-0

Chrastný V, Čadková E, Vaněk A, Teper L, Cabała J, Komárek M (2015) Cadmium isotope fractionation within the soil profile complicates source identification in relation to $\mathrm{Pb}-\mathrm{Zn}$ mining and smelting processes. Chem Geol 405:1-9. https://doi.org/10.1016/j.chemgeo. 2015.04.002

Çolak M, Gümrükçüoğlu M, Boysan F, Baysal E (2016) Determination and mapping of cadmium accumulation in plant leaves on the highway roadside, Turkey. Arch Environ Prot 42(3):11-16. https://doi. org/10.1515/aep-2016-0023

Dearing JA (1994) Environmental magnetic susceptibility. Using the Bartington MS2 system. Chi publishing, Kenilworth

Degryse F, Smolders E (2006) Mobility of Cd and $\mathrm{Zn}$ in polluted and unpolluted Spodosols. Eur J Soil Sci 57:122-133. https://doi.org/10. 1111/j.1365-2389.2005.00721.x 
Desaules A (2012) Critical evaluation of soil contamination assessment methods for trace metals. Sci Total Environ 426:120-131. https:// doi.org/10.1016/j.scitotenv.2012.03.035

Desaules A, Hämmann M, Weisskopf M (2001) Commentary on the ordinance of 1 July 1998 relating to impacts on the soil (OIS). Swiss Agency for the Environment, Forest and Landscape, Berne

Dziubanek G, Spychała A, Marchwińska-Wyrwał E, Rusin M, Hajok I, Ćwielag-Drabek M, Piekut A (2017) Long-term exposure to urban air pollution and the relationship with life expectancy in cohort of 3.5 million people in Silesia. Sci Total Environ 580:1-8. https://doi. org/10.1016/j.scitotenv.2016.11.217

Ettler V (2016) Soil contamination near non-ferrous metal smelters: a review. Appl Geochem 64:56-74. https://doi.org/10.1016/j. apgeochem.2015.09.020

Ferdyn M, Strzyszcz Z (2002) Heavy metal content in tree species and metallurgical slag from non-ferrous "Orzeł Biały" Plant in Piekary Śląskie. Arch Environ Prot 28(3):121-131 (in Polish)

Gałkiewicz T, Śliwiński S (1983) Geological characteristics of the Silesian-Cracovian lead-zinc ore deposits. Ann Soc Geol Pol 53(1-4):63-90 (in Polish)

Gałuszka A (2007) A review of geochemical background concepts and an example using data from Poland. Environ Geol 52:861-870. https:// doi.org/10.1007/s00254-006-0528-2

GDDKiA - The General Director for National Roads and Motorways, 2017: http://www.gddkia.gov.pl/userfiles/articles/g/generalnypomiar-ruchu-w-2015_15598//SYNTEZA/WYNIKI_GPR2015 DW.pdf

Górecka E (1993) Geological setting of the Silesian-Cracow Zn-Pb deposits. Geol Q 37(2):127-145

Hough RL, Breward N, Young SD, Crout NM, Tye AM (2004) Assessing potential risk of heavy metal exposure from consumption of homeproduced vegetables by urban populations. Environ Health Perspect 112:215-221. https://doi.org/10.1289/ehp.5589

Hunt A, Jones J, Oldfield F (1984) Magnetic measurements and heavy metals in atmospheric particulates of anthropogenic origin. Sci Total Environ 33:129-139. https://doi.org/10.1016/0048-9697(84)90387-

IRIS (2016) online database:https://www.epa.gov/sites/production/files/ 2016-06/documents/master sl table run may2016.pdf

Jordanova N (2016) Soil magnetism. Applications in pedology, environmental science and agriculture, 1st edition. Academic Press (Elsevier), p 466

Jordanova N, Jordanova D, Tsacheva T (2008) Application of magnetometry for delineation of anthropogenic pollution in areas covered by various soil types. Geoderma 144(3):557-571. https://doi.org/10. 1016/j.geoderma.2008.01.021

Jordanova D, Goddu SR, Kotsev T, Jordanova N (2013) Industrial contamination of alluvial soils near $\mathrm{Fe}-\mathrm{Pb}$ mining site revealed by magnetic and geochemical studies. Geoderma 192:237-248. https://doi. org/10.1016/j.geoderma.2012.07.004

Kabata-Pendias A, Pendias H (2001) Trace elements in soils and plants, 3rd edn. CRC Press, Boca Raton

Kapusta P, Sobczyk Ł (2015) Effects of heavy metal pollution from mining and smelting on enchytraeid communities under different land management and soil conditions. Sci Total Environ 536:517-526. https://doi.org/10.1016/j.scitotenv.2015.07.086

Kozłowska A, Mikołajczyk A, Boroń M, Kasperczyk S, Pawlas N (2015) Effects of lead exposure on the concentration of cadmium, selenium and values of morphology in the blood (in Polish). Environ Med 18(2):17-25

Kríbek B, Majer V, Knesl I, Keder J, Mapani B, Kamona F, Mihaljevič M, Ettler V, Penízek V, Vanek A, Sracek O (2016) Contamination of soil and grass in the Tsumeb smelter area, Namibia: modeling of contaminants dispersion and ground geochemical verification. Appl
Geochem 64:75-91. https://doi.org/10.1016/j.apgeochem.2015.07. 006

Kubicz J (2014) Health risk assessment for allotment gardens in Wrocław (in polish). Econ Environ 1(48):154-163

Kulka E, Gzyl J (2008) Assessment of lead and cadmium soil contamination in the vicinity of a non-ferrous metal smelter. Arch Environ Prot 34:105-115

Lanphear BP, Burgoon DA, Rust SW, Eberly S, Galke W (1998) Environmental exposures to lead and urban children's blood lead levels. Environ Res Sec A 76:120-130. https://doi.org/10.1006/ enrs.1997.3801

Leita L, De Nobili M, Mondini C, Muhlbachova G, Marchiol L, Bragato G, Contin M (1999) Influence of inorganic and organic fertilization on soil microbial biomass, metabolic quotient and heavy metal bioavailability. Biol Fertil Soils 28:371-376. https://doi.org/10.1007/ s003740050506

Li ZY, Ma ZW, Kuijp TJ, Yuan Z, Huang L (2014) A review of soil heavy metal pollution from mines in China: pollution and health risk assessment. Sci Total Environ 468-469:843-853. https://doi.org/10. 1016/j.scitotenv.2013.08.090

Liu X, Song Q, Tang Y, Li W, Xu J, Wu J, Wang F, Brookes PC (2013) Human health risk assessment of heavy metals in soil-vegetable system: a multi-medium analysis. Sci Total Environ 463-464:530 540. https://doi.org/10.1016/j.scitotenv.2013.06.064

Lu S, Yu X, Chen Y (2016) Magnetic properties, microstructure and mineralogical phases of technogenic magnetic particles (TMPs) in urban soils: their source identification and environmental implications. Sci Total Environ 543:239-247. https://doi.org/10.1016/j. scitotenv.2015.11.046

Magiera T, Strzyszcz Z, Kapička A, Petrovský E (2006) Discrimination of lithogenic and anthropogenic influences on topsoil magnetic susceptibility in Central Europe. Geoderma 130:299-311. https://doi. org/10.1016/j.geoderma.2005.02.002

Magiera T, Strzyszcz Z, Rachwał M (2007) Mapping particulate pollution loads using soil magnetometry in urban forests in the upper Silesia industrial region, Poland. Forest Ecol Manag 248(1-2):36-42. https://doi.org/10.1016/j. foreco.2007.02.034

Magiera T, Jabłońska M, Strzyszcz Z, Rachwał M (2011a) Morphological and mineralogical forms of technogenic magnetic particles in industrial dusts. Atmos Environ 45:4281-4290. https://doi.org/10.1016/j. atmosenv.2011.04.076

Magiera T, Jankowski M, Świtoniak M, Rachwał M (2011b) Study of forest soils on an area of magnetic and geochemical anomaly in north-eastern Poland. Geoderma 160(3-4):559-568. https://doi. org/10.1016/j.geoderma.2010.11.004

McMartin I, Henderson PJ, Plouffe A, Knight RD (2002) Comparison of $\mathrm{Cu}-\mathrm{Hg}-\mathrm{Ni}-\mathrm{Pb}$ concentrations in soils adjacent to anthropogenic point sources: examples from four Canadian sites. Geochem Explor Environ Anal 2:57-74. https://doi.org/10.1144/1467787302-007

Merrington G, Alloway BJ (1997) Determination of the residual metal binding characteristics of soils polluted by $\mathrm{cd}$ and $\mathrm{Pb}$. Water Air Soil Pollut 100:49-62. https://doi.org/10.1023/A:1018363812674

Müller G (1969) Index of geoaccumulation in sediments of the Rhine River. J Geol 2:108-118

Núñez O, Fernández-Navarro P, Martín-Méndez I, Bel-Lan A, Locutura JF, López-Abente G (2016) Arsenic and chromium topsoil levels and cancer mortality in Spain. Environ Sci Pollut Res 23:1766417675. https://doi.org/10.1007/s11356-016-6806-y

Petrovský E, Kapička A, Jordanova N, Knab M, Hoffmann V (2000) Low-field magnetic susceptibility: a proxy method of estimating increased pollution of different environmental systems. Environ Geol 39(3):312-318. https://doi.org/10.1007/s002540050010

Qing X, Yutong Z, Shenggao L (2015) Assessment of heavy metal pollution and human health risk in urban soils of steel industrial city 
(Anshan), Liaoning, Northeast China. Ecotoxicol Environ Saf 120: 377-385. https://doi.org/10.1016/j.ecoenv.2015.06.019

Rachwał M, Magiera T, Wawer M (2015) Coke industry and steel metallurgy as the source of soil contamination by technogenic magnetic particles, heavy metals and polycyclic aromatic hydrocarbons. Chemosphere 138:863-873. https://doi.org/10.1016/j. chemosphere.2014.11.077

Rachwał M, Kardel K, Magiera T, Bens O (2017) Application of magnetic susceptibility in assessment of heavy metal contamination of Saxonian soil (Germany) caused by industrial dust deposition. Geoderma 295:10-21. https://doi.org/10.1016/j.geoderma.2017.02. 007

Reimann C, de Caritat P (2005) Distinguishing between natural and anthropogenic sources for elements in the environment: regional geochemical surveys versus enrichment factors. Sci Total Environ 337: 91-107. https://doi.org/10.1016/j.scitotenv.2004.06.011

Rieuwerts JS, Searle P, Buck R (2006) Bioaccessible arsenic in the home environment in southwest England. Sci Total Environ 371:89-98. https://doi.org/10.1016/j.scitotenv.2006.08.039

Rożek D, Nadłonek W, Cabała J (2015) Forms of heavy metals (Zn, Pb, $\mathrm{Cd}$ ) occurring in rhizospheres from the areas of former and contemporary $\mathrm{Zn}-\mathrm{Pb}$ ore mining. Min Sci 22:125-138. https://doi.org/10. 5277/ms 150210

Rybicka EH (1996) Impact of mining and metallurgical industries on the environment in Poland. Appl Geochem 11:3-9. https://doi.org/10. 1016/0883-2927(95)00083-6

Šajn R, Aliu M, Stafilov T, Alijagič J (2013) Heavy metal contamination of topsoil around a lead and zinc smelter in Kosovska Mitrovica/ Mitrovice, Kosovo/Kosove. J Geochem Explor 134:1-16. https:// doi.org/10.1016/j.gexplo.2013.06.018

Steinnes E, Friedland AJ (2006) Metal contamination of natural surface soils from long-range atmospheric transport: existing and missing knowledge. Environ Rev 14(3):169-186. https://doi.org/10.1139/ a06-002

Steinnes E, Allen RO, Petersen HM, Rambæk JP, Varskog P (1997) Evidence of large scale heavy-metal contamination of natural surface soils in Norway from long-range atmospheric transport. Sci Total Environ 205(2-3):255-266. https://doi.org/10.1016/S00489697(97)00209-X

Strzyszcz Z (1993) Magnetic susceptibility of soils in the area influenced by industrial emissions. In: Schulin R, Desaules A, Webster R, von Steiger B (eds) Soil Monitoring. Monte Verità. Birkhäuser, Basel, pp 255-269. https://doi.org/10.1007/978-3-0348-7542-4_20

Strzyszcz Z, Magiera T, Heller F (1996) The influence of industrial emissions on the magnetic susceptibility of soils in upper Silesia. Stud Geophys Geod 40:276-286. https://doi.org/10.1007/BF02300743

Svendsen ML, Steinnes E, Blom HA (2011) Partitioning of metals in soil profiles near a zinc smelter. Chem Speciat Bioavailab 23(4):189 200. https://doi.org/10.3184/095422911X13103862613085

Tomlinson DL, Wilson JG, Harris CR, Jeffrey DW (1980) Problems in the assessment of heavy metal levels in estuaries and the formation of a pollution index. Helgolander Meeresun 33:566-575. https://doi. org/10.1007/BF02414780
Ullrich SM, Ramsey MH, Helios-Rybicka E (1999) Total and exchangeable concentrations of heavy metals in soils near Bytom, an area of $\mathrm{Pb} / \mathrm{Zn}$ mining and smelting in Upper Silesia, Poland. Appl Geochem 14:187-196. https://doi.org/10.1016/S0883-2927(98)00042-0

USEPA: US Environmental Protection Agency (1986) Guidelines for the Health Risk Assessment of Chemical Mixtures, vol 51. Federal Register, Washington DC

USEPA: US Environmental Protection Agency (2014) OSWER Directive 9200.1-120 and FAQ. Office of Solid Waste and Emergency Response, Washington, DC

Vaněk A, Chrastný V, Komárek M, Penížek V, Teper L, Cabała J, Drábek $\mathrm{O}$ (2013) Geochemical position of thallium in soils from a smelterimpacted area. J Geochem Explor 124:176-182. https://doi.org/10. 1016/j. gexplo.2012.09.002

Wang XS, Qin Y (2006) Use of multivariate statistical analysis to determine the relationship between the magnetic properties of urban topsoil and its metal, S, and Br content. Environ Geol 51(4):509-516. https://doi.org/10.1007/s00254-006-0347-5

Wang G, Zeng C, Zhang F, Zhang Y, Scott CA, Yan X (2017) Trafficrelated trace elements in soils along six highway segments on the Tibetan plateau: influence factors and spatial variation. Sci Total Environ 581-582:811-821. https://doi.org/10.1016/j.scitotenv. 2017.01.018

Warchulski R, Gawęda A, Kądziołka-Gaweł M, Szopa K (2015) Composition and element mobilization in pyrometallurgical slags from the Orzel Biały smelting plant in the Bytom-Piekary Śląskie area, Poland. Mineral Mag 79(2):459-483. https://doi.org/ 10.1180/minmag.2015.079.2.21

Wawer M, Rachwał M, Kowalska J (2017) Impact of noise barriers on the dispersal of solid pollutants from car emissions and their deposition in soil. Soil Sci Annu 68(1):19-26. https://doi.org/10.1515/ssa2017-0003

Wcisło E, Bronder J, Bubak A, Rodríguez-Valdés E, Gallego JLR (2016) Human health risk assessment in restoring safe and productive use of abandoned contaminated sites. Environ Int 94:436-448. https:// doi.org/10.1016/j.envint.2016.05.028

Wierzbicka M, Szarek-Łukaszewska G, Grodzińska K (2004) Highly toxic thallium in plants from the vicinity of Olkusz (Poland). Ecotoxicol Environ Saf 59:84-88. https://oi.org/10.1016/j.ecoenv. 2003.12.009

Wilhelm M, Ghosh JK, Su J, Cockburn M, Jerrett M, Ritz B (2012) Traffic-related air toxics and term low birth weight in Los Angeles County, California. Environ Health Perspect 120(1):132-138

Wiseman CLS, Zereini F, Püttmann W (2015) Metal and metalloid accumulation in cultivated urban soils: a medium-term study of trends in Toronto, Canada. Sci Total Environ 538:564-572. https://doi.org/ 10.1016/j.scitotenv.2015.08.085

Zawadzki J, Fabijańczyk P, Magiera T, Rachwał M (2015) Geostatistical microscale study of magnetic susceptibility in soil profile and magnetic indicators of potential soil pollution. Water Air Soil Pollut 226(5):142. https://doi.org/10.1007/s11270-015-2395-5 